\title{
INFORMED CONSENT STATUS IN OBSERVATIONAL STUDIES WITH RETROSPECTIVE DESIGN: A POOR SHOW
}

\author{
SUPREET KAUR GILL, VIKAS GUPTA, PARVEEN BANSAL*
}

Division of Clinical Research, University Centre of Excellence in Research, Baba Farid University of Health Sciences, Faridkot, Punjab, India. Email: ucer_bfuhs@rediffmail.com

Received: 14 December 2016, Revised and Accepted: 26 December 2016

\section{ABSTRACT}

Objective: Informed consent is very important to protect the rights of patients and is obtained as a vital component of any clinical study. Requirement of patient consent in retrospective research continues to stir controversy even today. Some of directions of regulatory authorities even waive off the consent for retrospective studies, whereas few recommend that at least clearance from the Ethical Review Board may be taken or information to patient may be given or oral consent must be given by patient for usage of the data in any retrospective study. The aim of this study was to analyze the current status of informed consent procedures in observational studies with retrospective design.

Methods: This review was intended to find out the current status of procedures involved in informed consent in India and abroad. A total of 100 retrospective studies were searched for this objective from the internet and other literature sources.

Results: Data show that in $65 \%$ of studies neither informed consent/oral consent nor ethical clearance was taken. Only $1 \%$ of studies have been conducted with informed consent as well as ethical clearance. Only $14 \%$ of studies were conducted with informed consent and $21 \%$ with ethical approval.

Conclusion: The study reflects very poor status of informed consent in retrospective studies and noncompliance of ICH guidelines for clinical research in relation to informed consent.

Keywords: Clinical research, Informed consent, Retrospective studies.

(C) 2017 The Authors. Published by Innovare Academic Sciences Pvt Ltd. This is an open access article under the CC BY license (http://creativecommons. org/licenses/by/4. 0/) DOI: http://dx.doi.org/10.22159/ajpcr.2017.v10i3.16588

\section{INTRODUCTION}

India has emerged as one of the preferred destinations for clinical trials of drugs by multinational pharmaceutical companies in recent years [1]. Quality of clinical trials relies on data consistency and subject safety. Ideally, all clinical trial ought to have a clinical trial quality management plan describing the tools that will be used to guarantee study quality. The adoption of quality-by-design and quality risk management methods for clinical trial management is the current mantra at Food and Drug Administration [2]. Retrospective clinical studies contribute a significant role in discovery or confirmation of important facts related to medicine. The issue of informed consent from participants has never been taken seriously by researchers for creating skewness in data resulting in the loss of important results $[3,4]$. Such skewness apprehends the researchers for exemption from need of informed consent. This finally makes the project leaders to overlook the basic ethics of informed consent and makes it further important for approval of an Institutional Ethics Committee (IEC). In general, patients may not be aware of use of data related to their ailment for other purposes and may feel offended as well as disappointed leading to loss of faith of their physicians. The risk further increases if the data are transferred to a third party not related with research group. As a matter of fact the usage of any data related to a subject in biobanks [5] and retrospective research (as explained in the international research guidelines of the Council for International Organizations of Medical Sciences [CIOMS]; commentary on guideline 4) can be used only with consent of the concerned subjects [6]. Informed consent enables a subject to adjudicate the pros and cons of the proposed medical treatment for final acceptance or refusal. This avoids or decreases the chances of errors, negligence, coercion, deception, and encourages the doctor's self-criticism. Informed consent is necessary in all studies of medical records and for use of sensitive personal information for research purposes.

Although as per memorandum of agreement in most countries, retrospective and epidemiological research is exempted from informed consent subject to preapproval by IEC, yet the scientific manipulations may easily find their way through ethics committees. According to Nuremberg Code 1949, informed consent must be obtained and is investigator's responsibility and no investigators should initiate epidemiological research involving human subjects without consent from subjects and a clear cut approval from legislation or competent authorities such as an Ethical Review Committee. Consent may be obtained in any way like voluntary actions, oral consent, signing a consent form. In the case of incompetence of the subject, a duly authorized representative should do so. Although in some communities, the family head is considered to give the consent but then also the voluntarily consent from the subject participating in the research is must. In addition in case of the minimal risk, ethical review committee may approve waiver of the requirement of a signed consent form. Such waivers may also be applied in case of unjustified threat to the subject's confidentiality.

Many bioethicists [7] and the Swiss Academy of Medical Sciences [8] opine that general consent in which patients receives information proportionate to the risks is sometimes sufficient. A broad consent to future research can be applied if these risks are low and patient may also refuse to provide general consent, and instead stipulate the use of data in only specific projects. Even for the research which involves the minimal risks to the patients or does not have any direct relation 
with the patients prior informed consent may be avoided however to ensure ethical importance of treating people with respect, information regarding right to leave the study should be clearly conveyed. It has been observed that researchers do not give much attention to this issue and hurriedly finish the retrospective analysis without keeping in view the interest of subjects and play with the rules and regulations setup by regulatory bodies. Hence, it was pertinent to find out the exact current status of informed consent procedures. The purpose of this study was to find out the current status of informed consent in observational studies with retrospective design in India and abroad.

\section{METHODS}

A total of 100 such observational studies with retrospective design involving 2,346,261 patients (Table 1) were reviewed from the internet and other literature resources. The status of the informed consent was

Table 1: Data showing name of retrospective study along with consent taken, number of subjects, and material use in retrospective studies

\begin{tabular}{|c|c|c|c|c|}
\hline S.No. & Title of the study/reference & $\begin{array}{l}\text { Informed } \\
\text { consent }\end{array}$ & $\begin{array}{l}\text { Number of } \\
\text { subjects }\end{array}$ & $\begin{array}{l}\text { Material used for } \\
\text { study }\end{array}$ \\
\hline 1 & Retrospective study in breast cancer patients supplemented with AHCC [10] & No & 58 & Medical records \\
\hline 2 & $\begin{array}{l}\text { A retrospective study on pathologic features and racial disparities in prostate } \\
\text { cancer [11] }\end{array}$ & No & 3000 & Pathology reports \\
\hline 3 & $\begin{array}{l}\text { Are antinuclear antibodies useful in neurologic patients? A retrospective analysis } \\
\text { based on } 545 \text { cases [12] }\end{array}$ & No & 545 & Laboratory reports \\
\hline 4 & Tobacco habits and risk of oral cancer: A retrospective study in India [13] & Yes & 520 & Cancer registry \\
\hline 5 & $\begin{array}{l}\text { A retrospective study on patients with Guillain-Barré syndrome treated } \\
\text { with therapeutic plasma exchange and other treatment options: A center's } \\
\text { experience [14] }\end{array}$ & Yes & 56 & Medical records \\
\hline 6 & $\begin{array}{l}\text { Profile of neurological problems in diabetes mellitus: Retrospective analysis of } \\
\text { data from } 1294 \text { patients [15] }\end{array}$ & No & 1294 & Medical records \\
\hline 7 & $\begin{array}{l}\text { Prognostic factors in cervical cancer: A hospital-based retrospective study from } \\
\text { Visakhapatnam city, Andhra Pradesh [16] }\end{array}$ & No & 552 & Treatment records \\
\hline 8 & $\begin{array}{l}\text { Neurologic cytomegalovirus complications in patients with aids: Retrospective } \\
\text { review of } 13 \text { cases and review of the literature [17] }\end{array}$ & IEC & 13 & Laboratory records \\
\hline 9 & $\begin{array}{l}\text { Neurological complications after renal transplantation: A retrospective clinical } \\
\text { study [18] }\end{array}$ & No & 19 & Medical records \\
\hline 10 & $\begin{array}{l}\text { Retrospective study of reasons for improved survival in patients with breast } \\
\text { cancer in East Anglia: Earlier diagnosis or better treatment [19] }\end{array}$ & No & 8630 & Cancer registry \\
\hline 11 & $\begin{array}{l}\text { A retrospective observational study of the relationship between family history } \\
\text { and survival from colorectal cancer [20] }\end{array}$ & No & 10937 & Cancer registry \\
\hline 12 & A retrospective study of gastric cancers in Tehran [21] & No & 460 & Pathology reports \\
\hline 13 & $\begin{array}{l}\text { Prevalence of inherited neurotransmitter disorders in patients with movement } \\
\text { disorders and epilepsy: A retrospective cohort study [22] }\end{array}$ & IEC & 154 & Medical records \\
\hline 14 & Etiologic spectrum of mental retardation and developmental delay in India [23] & No & 338 & Laboratory reports \\
\hline 15 & $\begin{array}{l}\text { Retrospective study of pulmonary hypertensive patients: Is right ventricular } \\
\text { myocardial performance index a vital prognostic factor? [24] }\end{array}$ & No & 93 & Medical records \\
\hline 16 & $\begin{array}{l}\text { Changes in physical activity and travel behaviors in residents of a mixed-use } \\
\text { development [25] }\end{array}$ & No & 101 & Subject's data \\
\hline 17 & $\begin{array}{l}\text { Anti-hypertensive prescribing patterns and cost analysis for primary } \\
\text { hypertension: A retrospective study [26] }\end{array}$ & No & 300 & Prescription data \\
\hline 18 & $\begin{array}{l}\text { A cross-sectional retrospective study to assess the pattern of prescribing for } \\
\text { inpatient hypertensive cases in a tertiary hospital and to find out the possible } \\
\text { avenues for betterment of hypertension management [27] }\end{array}$ & IEC & 261 & Medical records \\
\hline 19 & $\begin{array}{l}\text { Prevalence and risk factors of HIV in Faisalabad, Pakistan: A retrospective } \\
\text { study [28] }\end{array}$ & Yes & 31040 & Medical records \\
\hline 20 & Vaccination of patients with diabetes mellitus: A retrospective study [29] & No & 402 & Medical records \\
\hline 21 & $\begin{array}{l}\text { The impact of multifactorial genetic disorders on critical illness } \\
\text { insurance: A simulation study based on UK biobank [30] }\end{array}$ & No & 500,000 & $\begin{array}{l}\text { Medical histories/blood } \\
\text { samples }\end{array}$ \\
\hline 22 & $\begin{array}{l}\text { Major congenital anomalies: A five-year retrospective regional study in } \\
\text { Turkey [31] }\end{array}$ & IEC & 63,159 & Medical records \\
\hline 23 & $\begin{array}{l}\text { A retrospective study of pulmonary tuberculosis (PTB) prevalence among } \\
\text { patients attending infectious diseases hospital (IDH) in Kano, Nigeria [32] }\end{array}$ & No & 3679 & Laboratory reports \\
\hline 24 & $\begin{array}{l}\text { A retrospective study on incidence of pulmonary tuberculosis and human } \\
\text { immunodeficiency virus co-infection among patients attending National } \\
\text { Tuberculosis and Leprosy Control Program, Owo center [33] }\end{array}$ & No & 342 & Medical records \\
\hline 25 & $\begin{array}{l}\text { A retrospective study on the outcomes of tuberculosis treatment in Felege Hiwot } \\
\text { Referral Hospital, Northwest Ethiopia [34] }\end{array}$ & IEC & 756 & Medical records \\
\hline 26 & $\begin{array}{l}\text { Prevalence of XDR TB cases - a retrospective study from a tertiary care TB } \\
\text { hospital [35] }\end{array}$ & No & 223 & Laboratory reports \\
\hline 27 & $\begin{array}{l}\text { A retrospective study to determine the prevalence and outcome of tuberculosis } \\
\text { among patients who visited the TB Annex Hospital in Congo Town, Monrovia, } \\
\text { Liberia from July } 2009 \text { to July } 2010 \text { [36] }\end{array}$ & IEC & 299 & Medical records \\
\hline 28 & $\begin{array}{l}\text { Tuberculosis: An eight year (2000-2007) retrospective study at the University of } \\
\text { Malaya Medical Centre (UMMC), Kuala Lumpur, Malaysia [37] }\end{array}$ & No & 131 & Medical records \\
\hline 29 & Surgical safety checklist in obstetrics and gynecology [38] & No & 185,000 & Medical records \\
\hline
\end{tabular}


Table 1: (Continued)

\begin{tabular}{|c|c|c|c|c|}
\hline S.No. & Title of the study/reference & $\begin{array}{l}\text { Informed } \\
\text { consent }\end{array}$ & $\begin{array}{l}\text { Number of } \\
\text { subjects }\end{array}$ & $\begin{array}{l}\text { Material used for } \\
\text { study }\end{array}$ \\
\hline 30 & $\begin{array}{l}\text { Ectopic pregnancy and seasonal variation: A retrospective study from the South } \\
\text { Western Region of Saudi Arabia [39] }\end{array}$ & No & 21,564 & Medical records \\
\hline 31 & $\begin{array}{l}\text { Comparison of survival and complication rates of tooth-supported fixed dental } \\
\text { prostheses (FDPs) and implant-supported FDPs and single crowns (SCs) [40] }\end{array}$ & No & 85 & $\begin{array}{l}\text { Internet/electronic } \\
\text { search }\end{array}$ \\
\hline 32 & $\begin{array}{l}\text { A systematic review of the success of sinus floor elevation and survival of } \\
\text { implants inserted in combination with sinus floor elevation [41] }\end{array}$ & No & 12,020 & $\begin{array}{l}\text { Internet/electronic } \\
\text { search }\end{array}$ \\
\hline 33 & Timing of implant placement relative to tooth extraction [42] & No & 10 & $\begin{array}{l}\text { Internet/electronic } \\
\text { search }\end{array}$ \\
\hline 34 & $\begin{array}{l}\text { Photodynamic therapy as an adjunct to non-surgical periodontal treatment: } \\
\text { A randomized, controlled clinical trial [43] }\end{array}$ & Yes & 24 & Treatment records \\
\hline 35 & $\begin{array}{l}\text { The diagnosis and management of non-alcoholic fatty liver disease: Practice } \\
\text { guideline by the American association for the study of liver diseases, } \\
\text { American College of Gastroenterology, and the American Gastroenterological } \\
\text { Association [44] }\end{array}$ & No & 26,527 & Medical records \\
\hline 36 & $\begin{array}{l}\text { The outcomes of esophageal and gastric cancer treatments in a retrospective } \\
\text { study, single center experience [45] }\end{array}$ & No & 368 & Medical records \\
\hline 37 & $\begin{array}{l}\text { Gastric cancer in women: A regional health-center seven year retrospective } \\
\text { study [46] }\end{array}$ & Yes & 285 & Internet search \\
\hline 38 & $\begin{array}{l}\text { Clinical evaluation, prevalence and etiologic factors in patients with } \\
\text { ophthalmoplegia [47] }\end{array}$ & Yes & 226 & Laboratory reports \\
\hline 39 & Antipsychotic drugs and hyperglycemia in older patients with diabetes [48] & IEC & 13,817 & Prescription records \\
\hline 40 & Spectrum of Celiac Disease at Tertiary Care Center of Northern India [49] & No & 100 & Pathology reports \\
\hline 41 & $\begin{array}{l}\text { Risk of cancer from occupational exposure to ionizing radiation: Retrospective } \\
\text { cohort study of workers in France, the United Kingdom, and the United } \\
\text { States (INWORKS) [50] }\end{array}$ & No & 308297 & Medical records \\
\hline 42 & Metformin use and lung cancer risk in patients with diabetes [51] & No & 47,351 & Medical records. \\
\hline 43 & $\begin{array}{l}\text { HIV and cancer: A comparative retrospective study of Brazilian and U.S. clinical } \\
\text { cohort [52] (conducted in INI, } 2925 \text { patients and VCCC, } 3927 \text { patients) }\end{array}$ & Yes/No & $2,925 / 3,927$ & Medical records. \\
\hline 44 & $\begin{array}{l}\text { Retrospective analysis evaluating ovarian cancer cases presented at the clinical } \\
\text { oncology department, Alexandria University [53] }\end{array}$ & No & 116 & Cancer registry \\
\hline 45 & $\begin{array}{l}\text { Human papillomavirus (HPV) genome status and cervical cancer outcome: } \\
\text { A retrospective study [54] }\end{array}$ & IEC & 132 & Medical records \\
\hline 46 & $\begin{array}{l}\text { Oral squamous cell carcinoma: A retrospective study of } 740 \text { cases in a Brazilian } \\
\text { population [55] }\end{array}$ & No & 740 & Medical records \\
\hline 47 & $\begin{array}{l}\text { Neoadjuvant chemotherapy in advanced epithelial ovarian cancer: A retrospective } \\
\text { study [56] }\end{array}$ & No & 85 & Medical records \\
\hline 48 & $\begin{array}{l}\text { Retrospective study of cancer types in different ethnic groups and genders at } \\
\text { Karachi [57] }\end{array}$ & No & 5134 & Medical records \\
\hline 49 & $\begin{array}{l}\text { A new prognostic system for hepatocellular carcinoma: A retrospective study of } \\
435 \text { patients [58] }\end{array}$ & No & 435 & Laboratory reports \\
\hline 50 & Timeliness of lung cancer care in Victoria: A retrospective cohort study [59] & IEC & 1417 & Cancer registry \\
\hline 51 & $\begin{array}{l}\text { Effect of neuraxial anesthesia on tumor progression in cervical cancer patients } \\
\text { treated with brachytherapy: A retrospective cohort study [60] }\end{array}$ & IEC & 132 & Cancer registry \\
\hline 52 & Pattern and trends of cancer in Odisha, India: A retrospective study [61] & No & 74861 & Cancer registry \\
\hline 53 & Long term follow up and retrospective study on 533 gastric cancer cases [62] & Yes & 533 & Cancer registry \\
\hline 54 & $\begin{array}{l}\text { A retrospective study of the outcome of cesarean section for women with severe } \\
\text { pre-eclampsia in a third world setting [63] }\end{array}$ & No & 1156 & Medical records \\
\hline 55 & Retrospective evaluation of anesthesia approaches for lumbar disc surgery [64] & IEC & 328 & Medical records \\
\hline 56 & $\begin{array}{l}\text { Caesarean section for placenta praevia: A retrospective study of anesthetic } \\
\text { management [65] }\end{array}$ & No & 350 & Medical records \\
\hline 57 & $\begin{array}{l}\text { Retrospective data collection and analytical techniques for patient safety } \\
\text { studies [66] }\end{array}$ & No & 277 & Medical records \\
\hline 58 & Anesthesia for awake craniotomy: A retrospective study of 54 cases [67] & IEC & 54 & Medical records \\
\hline 59 & Anesthesia and cancer recurrence: What is the evidence? [68] & No & 129 & \\
\hline 60 & $\begin{array}{l}\text { A five-year retrospective study on the common microbial isolates and sensitivity } \\
\text { pattern on blood culture of pediatric cancer patients admitted at the Philippine } \\
\text { general hospital for febrile neutropenia [69] }\end{array}$ & No & 90 & Laboratory reports \\
\hline 61 & $\begin{array}{l}\text { Retrospective study on risk habits among oral cancer patients in Karnataka } \\
\text { Cancer Therapy and Research Institute, Hubli, India [70] }\end{array}$ & No & 1,472 & Medical records \\
\hline 62 & Oral cancer in the UAE: A multicenter, retrospective study [71] & No & 992 & Pathology reports \\
\hline 63 & Incidence of second primary oral cancer tumors: A retrospective study [72] & IEC & 34,637 & Medical records \\
\hline 64 & $\begin{array}{l}\text { Survival of dental implants in patients with oral cancer treated by surgery and } \\
\text { radiotherapy: A retrospective study [73] }\end{array}$ & Yes & 34 & Medical histories \\
\hline 65 & Demographic and clinical profile of oral lichen planus: A retrospective study [74] & No & 128 & Pathology reports \\
\hline 66 & $\begin{array}{l}\text { Retrospective study of the frequency of oral squamous cell carcinoma in the } \\
\text { population of Volta Redonda, Rio de Janeiro, Brazil [75] }\end{array}$ & No & 5880 & Pathology reports \\
\hline 67 & Metabolic syndrome in adults with congenital heart disease [76] & IEC & 150104 & Treatment records \\
\hline
\end{tabular}


Table 1: (Continued)

\begin{tabular}{|c|c|c|c|c|}
\hline S.No. & Title of the study/reference & $\begin{array}{l}\text { Informed } \\
\text { consent }\end{array}$ & $\begin{array}{l}\text { Number of } \\
\text { subjects }\end{array}$ & $\begin{array}{l}\text { Material used for } \\
\text { study }\end{array}$ \\
\hline 68 & $\begin{array}{l}\text { High prevalence of cardiovascular diseases among other medically compromised } \\
\text { conditions in dental patients: A retrospective study [77] }\end{array}$ & No & 36,729 & Medical records \\
\hline 69 & $\begin{array}{l}\text { Cardiovascular disease in asthma and COPD: A population-based retrospective } \\
\text { cross-sectional study [78] }\end{array}$ & Yes & 909,638 & Medical records \\
\hline 70 & $\begin{array}{l}\text { A multicenter retrospective study defining the clinical and hematological } \\
\text { manifestations of brucellosis and pancytopenia in a large series: Hematological } \\
\text { malignancies, the unusual cause of pancytopenia in patients with brucellosis [79] }\end{array}$ & No & 202 & Medical records \\
\hline 71 & $\begin{array}{l}\text { Invasive infections caused by Trichosporon species and geotrichum capitatum in } \\
\text { patients with hematological malignancies: A retrospective multi-centric study } \\
\text { from Italy and review of the literature [80] }\end{array}$ & No & 52 & Laboratory reports \\
\hline 72 & $\begin{array}{l}\text { Respiratory diseases morbidity and mortality among adults attending a tertiary } \\
\text { hospital in Nigeria [81] }\end{array}$ & IEC & 183 & Laboratory reports \\
\hline 73 & $\begin{array}{l}\text { Prevalence of respiratory diseases in hospitalized patients in Saudi Arabia: } \\
\text { A } 5 \text { years study 1996-2000 [82] }\end{array}$ & No & 810 & Medical records \\
\hline 74 & $\begin{array}{l}\text { Drug utilization patterns in the emergency department: A retrospective } \\
\text { study [83] }\end{array}$ & IEC & 300 & Medical records \\
\hline 75 & $\begin{array}{l}\text { Primary gastrointestinal non-Hodgkin's lymphoma: A retrospective study with } \\
\text { emphasis on prognostic factors and treatment outcome [84] }\end{array}$ & No & 208 & Pathology reports \\
\hline 76 & $\begin{array}{l}\text { Gastrointestinal lymphomas: Pattern of distribution and histological subtypes: } \\
10 \text { years' experience in a tertiary center in South India [85] }\end{array}$ & No & 361 & Pathology reports \\
\hline 77 & Pediatric anaphylaxis: A 5 year retrospective review [86] & IEC & 117 & Medical records \\
\hline 78 & $\begin{array}{l}\text { Interpretation of upper gastrointestinal tract endoscopic biopsies: A retrospective } \\
\text { study [87] }\end{array}$ & No & 100 & Pathology reports \\
\hline 79 & $\begin{array}{l}\text { Retrospective study of cancer types in different ethnic groups and genders at } \\
\text { Karachi [57] }\end{array}$ & No & 5134 & Medical histories \\
\hline 80 & Primary extra nodal non-Hodgkin lymphoma: A 5 year retrospective analysis [88] & No & 68 & Pathology reports \\
\hline 81 & Gastrointestinal stromal tumors and extra-gastrointestinal tract neoplasms [89] & No & 21 & Pathology reports \\
\hline 82 & $\begin{array}{l}\text { ACE gene polymorphism: Ischemic heart disease and longevity in } 10150 \\
\text { individuals: A case-referent and retrospective cohort study based on the } \\
\text { Copenhagen city heart study [90] }\end{array}$ & IEC & 7263 & Medical records \\
\hline 83 & $\begin{array}{l}\text { New autoimmune diseases after cord blood transplantation: A retrospective } \\
\text { study of EUROCORD and the Autoimmune Disease Working Party of the European } \\
\text { Group for Blood and Marrow Transplantation [91] }\end{array}$ & Yes & 726 & Laboratory reports \\
\hline 84 & $\begin{array}{l}\text { Retrospective multivariate analysis of hepatic veno-occlusive disease after blood } \\
\text { or marrow transplantation: Possible beneficial use of low molecular weight } \\
\text { heparin [92] }\end{array}$ & No & 462 & Medical records \\
\hline 85 & $\begin{array}{l}\text { Bacteremia in hospitalized patients with malignant blood disorders: } \\
\text { A retrospective study of causative agents and their resistance profiles during a } \\
\text { 14-year period without antibacterial prophylaxis [93] }\end{array}$ & No & 1402 & Treatment records \\
\hline 86 & $\begin{array}{l}\text { Demographic and clinical profile of oral squamous cell carcinoma patients: } \\
\text { A retrospective study [94] }\end{array}$ & IEC & 295 & Cancer registry \\
\hline 87 & $\begin{array}{l}\text { Oral squamous cell carcinoma: A retrospective study of } 740 \text { cases in a Brazilian } \\
\text { population [55] }\end{array}$ & No & 740 & Medical records \\
\hline 88 & $\begin{array}{l}\text { Epidemiology of oral and pharyngeal cancer at the National Cancer Institute, } \\
\text { Cairo [95] }\end{array}$ & Yes & 71 & Medical histories \\
\hline 89 & $\begin{array}{l}\text { A retrospective study of survival in breast cancer patients undergoing deuterium } \\
\text { depletion in addition to conventional therapies [96] }\end{array}$ & No & 232 & Pathology reports \\
\hline 90 & Malignant skin tumors in Misurata Cancer Center during 2011-2014 [97] & No & 195 & Pathology reports \\
\hline 91 & $\begin{array}{l}\text { Assessment of clinical diagnostic accuracy compared with pathological diagnosis } \\
\text { of basal cell carcinoma [98] }\end{array}$ & IEC & 367 & Pathology reports \\
\hline 92 & Pattern of skin cancer in South Western Saudi Arabia [99] & No & 193 & Pathology reports \\
\hline 93 & $\begin{array}{l}\text { Retrospective analysis of melanocytic lesions in children at the National Cancer } \\
\text { Institute [100] }\end{array}$ & No & 102 & Medical records \\
\hline 94 & A retrospective study of treatment of squamous cell carcinoma in situ [101] & IEC & 239 & Laboratory reports \\
\hline 95 & $\begin{array}{l}\text { A retrospective analysis of occupational exposure to pesticides as a possible risk } \\
\text { factor for non-melanoma skin cancers [102] }\end{array}$ & No & 124 & Pathology reports \\
\hline 96 & $\begin{array}{l}\text { An epidemiological review of skin cancers in Malwa belt of Punjab India: A 3-year } \\
\text { clinicopathological study [103] }\end{array}$ & IEC & 52 & Pathology reports \\
\hline 97 & $\begin{array}{l}\text { Dermatological malignancies in Kano, Northern Nigeria: A histopathological } \\
\text { review [104] }\end{array}$ & No & 125 & Pathology reports \\
\hline 98 & $\begin{array}{l}\text { Epidemiology of nonmelanoma and melanoma skin cancer in Zagreb, } \\
\text { Croatia [105] }\end{array}$ & No & 16938 & Pathology reports \\
\hline 99 & $\begin{array}{l}\text { Retrospective study of papulonodular skin lesions and their clinopathological } \\
\text { correlation [106] }\end{array}$ & Yes & 75 & Laboratory reports \\
\hline 100 & $\begin{array}{l}\text { A retrospective study investigating the rate of HER2 discordance between primary } \\
\text { breast carcinoma and locoregional or metastatic disease [107] }\end{array}$ & Yes & 157 & Pathology reports \\
\hline
\end{tabular}


evaluated in the retrospective studies. A record of informed consent from subjects or approval of study from the IEC was taken after the study was made.

\section{RESULTS AND DISCUSSION}

A total of 100 studies were reviewed. The informed consent was obtained in only $14 \%$ of studies and the rest $86 \%$ of the studies were conducted without the consent of the subjects and even the patient or subject might be unaware of their contribution in the research or their involvement in the studies. Of 100 only in 21 studies the approval from the ethical committee was taken. Only one study out of 100 studies has been conducted with patient information as well as ethical clearance from the Ethical Review Board. This clearly shows the poor status of informed consent in the studies with retrospective design (Fig. 1). It was also observed that on the whole around 65 studies out of 100 were

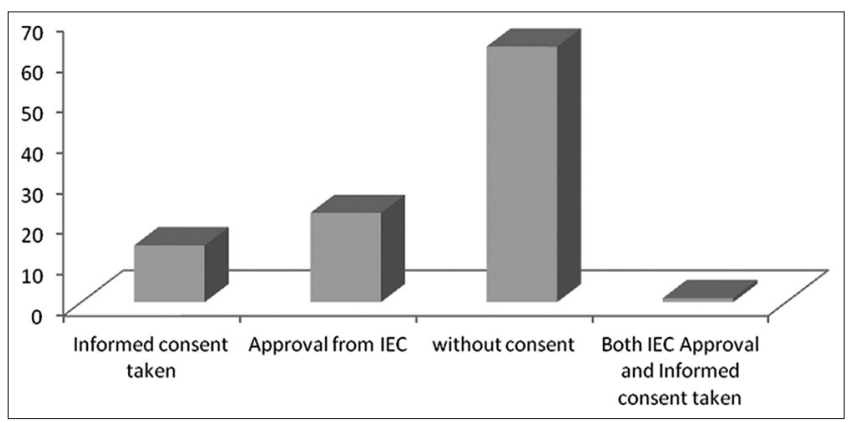

Figure 1: Status of informed consent in retrospective studies

Table 2: Data of material used and subject number for retrospective studies

\begin{tabular}{lll}
\hline Type of data & Number & Total number of subjects \\
\hline Pathology reports & 20 & 29,701 \\
Medical records & 42 & $1,742,136$ \\
Laboratory reports & 13 & 6,824 \\
Cancer registry & 9 & 12,400 \\
Treatment records & 4 & 152,058 \\
Prescription data & 2 & 14,117 \\
Internet/electronic search & 5 & 12,400 \\
Medical histories & 5 & 505,306 \\
\hline
\end{tabular}

conducted without the ethical approval and the consent of the patients. Moreover, these studies used the data of around approximately $2,509,099$ patients. The total number of subjects who were informed regarding their involvement in the study is approximately 946,488. The rest of 1,562,611 patients were unaware about their participation in the study. The British Sociological Association's Statement of Ethical Practice [9] depicts that informed consent for use of data and any other material should be obtained by researchers without which the existence of basic ethical norms relating to clinical research and personal privacy will be contradicted. All other major regulatory authorities also emphasize the same point. However, in our results, it is very clearly reflected that the principles of protection of patient rights is deliberately violated.

In addition, other interesting information from study was that out of 100 studies around 50 studies are on cancer. This indicates that for cancer research, retrospective studies might play a great role. The data show that the commonly used material for the retrospective studies (Table 2) are pathology reports, medical record, laboratory reports, cancer registry data, treatment records, prescription data, and PubMed/Electronic search. In around 33 studies, the pathology and laboratory reports have been used, 42 studies involve the medical record of patients, 9 studies include cancer registry data, 6 involved the treatment records and prescription data and in only 5 studies the internet search/PubMed/electronic search was carried out. Results are suggestive of voracious use of medical records for retrospective studies.

Authors have also analyzed the number of publications published without the IEC approval against the Committee on Publication Ethics (COPE) regulations out of these 100 studies (Table 3). It clearly indicates $66 \%$ of papers in which informed consent and institutional ethical approval have not been taken for the retrospective study. If we go back in year 2000 then it is bit possible that papers could be published against COPE regulations but data of this study show that significant number of papers have been published without the informed consent and ethical approval even in 2011-2015. The COPE was found in 1997 to address breaches of research and publication ethics [108]. According to the COPE guidelines the good research should be well justified, well planned, appropriately designed, and ethically approved. Fully informed consent should always be sought. If according to the circumstances it is not possible to take informed consent the approval or decision from the ethics committee is acceptable. When participants are unable to give fully informed consent, research should follow international guidelines, such as those of the CIOMS. Authors for the publication of their work

Table 3: Year of publication of papers (out of $n=100$ studies) against COPE

\begin{tabular}{|c|c|c|c|c|c|}
\hline $\begin{array}{l}\text { Year of publication of } \\
\text { study }\end{array}$ & Total no. of studies & IEC approval & Informed consent & No IEC/No informed consent & $\begin{array}{l}\text { \% studies published } \\
\text { against COPE }\end{array}$ \\
\hline 2016 & 3 & 3 & - & - & 0 \\
\hline 2015 & 17 & 5 & 5 & 7 & 41.1 \\
\hline 2014 & 10 & 2 & 2 & 6 & 60 \\
\hline 2013 & 9 & 1 & 1 & 7 & 77.7 \\
\hline 2012 & 11 & 1 & 3 & 7 & 63.6 \\
\hline 2011 & 9 & 1 & 1 & 7 & 77.7 \\
\hline 2009 & 6 & 3 & 1 & 2 & 33.3 \\
\hline 2008 & 9 & 1 & 1 & 7 & 77.7 \\
\hline 2007 & 2 & - & - & 2 & 100 \\
\hline 2006 & 3 & - & - & 3 & 100 \\
\hline 2005 & 2 & - & - & 2 & 100 \\
\hline 2004 & 3 & - & - & 3 & 100 \\
\hline 2003 & 2 & - & - & 2 & 100 \\
\hline 2002 & 1 & - & - & 1 & 100 \\
\hline 2000 & 1 & - & - & 1 & 100 \\
\hline 1998 & 1 & - & - & 1 & 100 \\
\hline 1997 & 2 & 1 & - & 1 & 50 \\
\hline Total & 100 & 21 & 14 & 65 & 65 \\
\hline
\end{tabular}

COPE: Committee on Publication Ethics, IEC: Institutional Ethics Committee 
must follow the World Medical Association's Declaration of Helsinki. The journals have a duty to consider the ethical aspects of both submitted and published work. It is required that every research article submitted to any journal must include a statement that the study obtained ethics approval including the name of the ethics committee or institutional review board and a statement that participants gave informed consent before taking part. The international committee of medical journal editors [109] states that the requirement for informed consent should be included in the journal's instructions for authors. Research should be conducted in accordance with the Helsinki and approval from IEC must be taken. However, our results are indicative that the publishing rules are also being violated. The publishing houses are publishing the paper even without the informed consent and institutional ethical approval.

\section{Strength and limitations of the study}

Strength of the study is that the objective parameter (informed consent/ ethical clearance) is not affected by design of studies as the design in case-series study, cross sectional study, case control study and a historic cohort study are different. As this study represents limited data of 100 observational studies with retrospective design, the data may not be representative of all the retrospective studies conducted.

\section{CONCLUSION}

From the analysis it is clear that observational studies with retrospective design are of immense use for generating data; however, a conscious violation of rules and regulations have been made and is being made continuously by investigators for not taking informed consent/ethical approval of retrospective studies. Before the participation of subject in the research, the consent must be obtained so that the right of voluntariness is respected. Regulatory bodies must tighten the noose to ensure ethical clearance of all the retrospectively designed studies. It should be made mandatory for the journals to take the ethical clearance certificate from authors before publication of any study including human subjects.

\section{ACKNOWLEDGMENT}

Authors are thankful to Baba Farid University of Health Sciences, Faridkot (Punjab) for providing the necessary facilities during this work.

\section{REFERENCES}

1. Bhowmik D, Chandira M, Chiranjib B. Emerging trends of scope and opportunities clinical trials in India. Int $\mathrm{J}$ Pharm Pharm Sci 2010;2(1):7-20.

2. Johnson J, Gupta NV. Recent advances in quality management of clinical trials. Int J Pharm Pharm Sci 2013;5(3):34-8.

3. Al-Shahi R, Vousden C, Warlow C; Scottish Intracranial Vascular Malformation Study (SIVMS) Steering Committee. Bias from requiring explicit consent from all participants in observational research: Prospective, population based study. BMJ 2005;331(7522):942.

4. Junghans C, Feder G, Hemingway H, Timmis A, Jones M. Recruiting patients to medical research: Double blind, randomised trial of "opt-in" versus “opt-out" strategies. BMJ 2005;331(7522):940-2.

5. WMA: The World Medical Association. Declaration on Ethical Considerations Regarding Health Databases; 2002. Available from: http://www.wma.net/e/policy/d1.html. [Last accessed on $2009 \mathrm{Jul} 30$ ].

6. CIOMS: Council for International Organizations of Medical Sciences. International Ethical Guidelines for Biomedical Research Involving Human Subjects. Available from: http://www.cioms.ch/frame_ guidelines nov 2002.html. [Last accessed on 2009 Aug 10].

7. Capron AM, Mauron A, Elger BS, Boggio A, Ganguli-Mitra A, BillerAndorno N. Ethical norms and the international governance of genetic databases and biobanks: Findings from an international study. Kennedy Inst Ethics J 2009;19(2):101-24.

8. SAMS. Directive on Biobanks, Obtainment, Preservation and Utilisation of Human Biological Material. Basel: SAMS; 2006.

9. British Sociological Association. Statement of Ethical Practice. Durham: British Sociological Association Appendix; 2004.

10. Matsui Y, Kamiyama Y. Retrospective study in breast cancer patients supplemented with AHCC. Int J Integr Oncol 2009;3(2):12-6.
11. Bigler SA, Pound CR, Zhou X. A retrospective study on pathologic features and racial disparities in prostate cancer. Prostate Cancer 2011;2011:239460.

12. Eschle D, Wieser HG. Are antinuclear antibodies useful in neurologic patients? A retrospective analysis based on 545 cases. Schweiz Arch Neurol Psychiatr 2004;155(2);67-9.

13. Mathur A, Jain M, Shiva M, Navlakha M, Prabu, Kulkarni S. Tobacco habits and risk of oral cancer: A retrospective study in India. Iran J Blood Cancer 2009;1(3):111-6.

14. Kozanoglu I, Deniz Y, Buyukkurt N, Yeral M, Boga C, Ozdogu H. A retrospective study on patients with guillain-barré syndrome treated with therapeutic plasma exchange and other treatment options A centre's experience. Eur Neurol Rev 2015;10(1):81-4.

15. Zargar AH, Sofi FA, Laway BA, Masoodi SR, Shah NA, Dar FA. Profile of neurological problems in diabetes mellitus: Retrospective analysis of data from 1294 patients. Health Adm 2009;22:95-106.

16. Kumari KG, Sudhakar G, Ramesh M, Kalpana VL, Paddaiah G. Prognostic factors in cervical cancer: A hospital-based retrospective study from Visakhapatnam City, Andhra Pradesh. J Life Sci 2010;2(2):99-105.

17. Silva CA, Oliveira AC, Vilas-Boas L, Fink MC, Pannuti CS, Vidal JE. Neurologic cytomegalovirus complications in patients with AIDS: Retrospective review of 13 cases and review of the literature. Rev Inst Med Trop Sao Paulo 2010;52(6):305-10.

18. Cengiz N, Adibelli Z, Yakupoğlu YK, Türker H. Neurological complications after renal transplantation: A retrospective clinical study. Arch Neuropsychiatry 2015;52:331-5.

19. Stockton D, Davies T, Day N, McCann J. Retrospective study of reasons for improved survival in patients with breast cancer in East Anglia: Earlier diagnosis or better treatment. BMJ 1997;314(7079):472-5.

20. Morris EJ, Penegar S, Whitehouse LE, Quirke P, Finan P, Bishop DT, et al. A retrospective observational study of the relationship between family history and survival from colorectal cancer. $\mathrm{Br} \mathrm{J}$ Cancer 2013;108(7):1502-7.

21. Pishbijari HF, Rad MA, Ghofrani H, Shafaghi A, Toosi MN, Dolatshahi S, et al. A retrospective study of gastric cancers in Tehran. Med J Islam Repub Iran 2006;20(3):107-10.

22. Mercimek-Mahmutoglu S, Sidky S, Hyland K, Patel J, et al. Prevalence of inherited neurotransmitter disorders in patients with movement disorders and epilepsy: A retrospective cohort study. Orphanet J Rare Dis 2015;10:12.

23. Aggarwal S, Bogula VR, Mandal K, Kumar R, Phadke SR. Aetiologic spectrum of mental retardation and developmental delay in India. Indian J Med Res 2012;136(3):436-44.

24. Grapsa I, Pavlopoulos H, Dawson D, Gibbs JS, Nihoyannopoulos P. Retrospective study of pulmonary hypertensive patients: Is right ventricular myocardial performance index a vital prognostic factor? Hellenic J Cardiol 2007;48(3):152-60.

25. Mumford KG, Contant CK, Weissman J, Wolf J, Glanz K. Changes in physical activity and travel behaviors in residents of a mixed-use development. Am J Prev Med 2011;41(5):504-7.

26. Pr R, Hv A, Shivamurthy M. Anti hypertensive prescribing patterns and cost analysis for primary hypertension: A retrospective study. J Clin Diagn Res 2014;8(9):HC19-22.

27. Gupta SK, Nayak RP, Rahavi R, Kumar A. A cross-sectional retrospective study to assess the pattern of prescribing for inpatient hypertensive cases in a tertiary hospital and to find out the possible avenues for betterment of hypertension management. Arch Med Health Sci 2015;3(1):60-5.

28. Maan MA, Hussain F, Jamil M. Prevalence and risk factors of HIV in Faisalabad, Pakistan -A retrospective study. Pak J Med Sci 2014;30(1):32-5.

29. Mad'ar R, Benesová D, Brandejská D, Cermáková M, Dvorková A, Gazárková $\mathrm{O}$, et al. Vaccination of patients with diabetes mellitus - A retrospective study. Cent Eur J Public Health 2011;19(2):98-101.

30. Macdonald A, Pritchard D, Tapadar P. The impact of multifactorial genetic disorders on critical illness insurance: A simulation study based on UK Biobank. Astin Bull 2006;36(2):311-46.

31. Tomatir AG, Demirhan H, Sorkun HC, Köksal A, Ozerdem F, Cilengir N. Major congenital anomalies: A five-year retrospective regional study in Turkey. Genet Mol Res 2009;8(1):19-27.

32. Imam TS, Oyeyi TI. A retrospective study of pulmonary tuberculosis (Ptb) prevalence amongst patients attending infectious diseases hospital (IDH) in Kano, Nigeria. Bayero J Pure Appl Sci 2008;1(1):10-5.

33. Ojiezeh TI, Ogundipe OO, Adefosoye VA. A retrospective study on incidence of pulmonary tuberculosis and human immunodeficiency 
virus co-infection among patients attending national tuberculosis and leprosy control programme, OWO Centre. The Pan Afr Med J 2015;20:345.

34. Biadglegne F, Anagaw B, Debebe T, Anagaw B, Tesfaye W, Tessema B, et al. A retrospective study on the outcomes of tuberculosis treatment in Felege Hiwot Referral Hospital, Northwest Ethiopia. Int J Med Med Sci 2013;5(2):85-91.

35. Myneedu VP, Visalakshi P, Verma AK, Behera D, Bhalla M. Prevalence of XDR TB cases - A retrospective study from a tertiary care TB hospital. Indian J Tuberc 2011;58(2):54-9.

36. Kpanyen PN, Diouf G, Tokpa AF, Toe MW, Nie S. A retrospective study to determine the prevalence and outcome of tuberculosis among patients who visited the TB Annex Hospital in Congo Town, Monrovia, Liberia from July 2009 to July 2010. Glob J Health Sci 2011;3(1):110-8.

37. Jetan CA, Jamaiah I, Rohela M, Nissapatorn V. Tuberculosis: An eight year (2000-2007) retrospective study at the University of Malaya Medical Centre (UMMC), Kuala Lumpur, Malaysia. Southeast Asian J Trop Med Public Health 2010;41(2):378-85.

38. Singh SS, Mehra N, Hopkins L; Society of Obstetricians and Gynecologists of Canada. Surgical safety checklist in obstetrics and gynaecology. J Obstet Gynaecol Can 2013;35(1):82-5.

39. Eskandar M, Archibong EI, Sadek AA, Sobande AA. Ectopic pregnancy and seasonal variation: A retrospective study from the south western region of Saudi Arabia. Bahrain Med Bull 2002;24(2):63-5.

40. Pjetursson BE, Tan WC, Tan K, Brägger U, Zwahlen M, Lang NP. A systematic review of the survival and complication rates of resinbonded bridges after an observation period of at least 5 years. Clin Oral Implants Res 2008;19(2):131-41.

41. Pjetursson BE, Tan WC, Zwahlen M, Lang NP. A systematic review of the success of sinus floor elevation and survival of implants inserted in combination with sinus floor elevation. J Clin Periodontol 2008;35 8 Suppl:216-40

42. Schropp L, Isidor F. Timing of implant placement relative to tooth extraction. J Oral Rehabil 2008;35 Suppl 1:33-43.

43. Christodoulides N, Nikolidakis D, Chondros P, Becker J, Schwarz F, Rössler R, et al. Photodynamic therapy as an adjunct to non-surgical periodontal treatment: A randomized, controlled clinical trial. J Periodontol 2008;79(9):1638-44.

44. Chalasani N, Younossi Z, Lavine JE, Diehl AM, Brunt EM, Cusi K, et al. The diagnosis and management of non-alcoholic fatty liver disease: Practice guideline by the American association for the study of liver diseases, American college of gastroenterology, and the American gastroenterological association. Hepatology 2012;55(6):2005-23.

45. Alimoghaddam K, Jalali A, Aliabadi LS, Ghaffari F, Maheri R, Eini E, et al. The outcomes of esophageal and gastric cancer treatments in a retrospective study, single center experience. Int J Hematol Oncol Stem Cell Res 2014;8(2):9-13.

46. Suryawala K, Soliman D, Mutyala M, Nageeb S, Boktor M, Seth A, et al. Gastric cancer in women: A regional health-center seven year retrospective study. World J Gastroenterol 2015;21(5):7805-13

47. Afshinmajd S, Ghasemi H, Rajabi MT, Jalili M, Yarmohammadi ME. Clinical evaluation, prevalence and etiologic factors in patients with ophthalmoplegia. Iran J Ophthalmol 2011;23(1):48-54.

48. Lipscombe LL, Lévesque L, Gruneir A, Fischer HD, Juurlink DN, Gill SS, et al. Antipsychotic drugs and hyperglycemia in older patients with diabetes. Arch Intern Med 2009;169(14):1282-9.

49. Parveen M, Pansi, Sonia C, Vani M, Ajay C. Spectrum of celiac disease at tertiary care center of Northeren India. Adv Res Gastroentero Hepatol 2015;1(2):555-8.

50. Richardson DB, Daniels RD, Gillies M, Cardis E, O'Hagan JA, Hamra GB, et al. Risk of cancer from occupational exposure to ionising radiation: Retrospective cohort study of workers in France, the United Kingdom, and the United States (INWORKS). BMJ 2015;351(6634):1-8.

51. Sakoda LC, Ferrara A, Achacoso NS, Peng T, Ehrlich SF, Quesenberry CP Jr, et al. Metformin use and lung cancer risk in patients with diabetes. Cancer Prev Res (Phila). 2015;8(2):174-9.

52. Castilho JL, Luz PM, Shepherd BE, Turner M, Ribeiro SR, Bebawy SS, et al. HIV and cancer: A comparative retrospective study of Brazilian and U.S. Clinical cohorts. Infect Agent Cancer 2015;10:4.

53. Mostafa MF, El-Etreby N, Awad N. Retrospective analysis evaluating ovarian cancer cases presented at the clinical oncology department, Alexandria University. Alex J Med 2012;48(4):353-60.

54. Das P, Thomas A, Kannan S, Deodhar K, Shrivastava SK, Mahantshetty U, et al. Human papillomavirus (HPV) genome status and cervical cancer outcome - A retrospective study. Indian J Med Res
2015;142(5):525-32.

55. Gervásio OL, Dutra RA, Tartaglia SM, Vasconcellos WA, Barbosa AA, Aguiar MC. Oral squamous cell carcinoma: A retrospective study of 740 cases in a Brazilian population. Braz Dent J 2001;12(1):57-61.

56. Sharma S, Vijaykumar DK, Chitrathara K, Haji AG, George RC, Pavithran K. Neoadjuvant chemotherapy in advanced epithelial ovarian cancer: A retrospective study. Indian J Med Paediatr Oncol 2007;28(1):7-13.

57. Khaliq SA, Naqvi SB, Fatima A. Retrospective study of cancer types in different ethnic groups and genders at Karachi. Springerplus 2013;2(1):118.

58. A new prognostic system for hepatocellular carcinoma: A retrospective study of patients: The cancer of the liver Italian program (CLIP) investigators. Hepatology 1998;28(3):751-5.

59. Evans SM, Earnest A, Bower W, Senthuren M, McLaughlin P, Stirling R. Timeliness of lung cancer care in Victoria: A retrospective cohort study. Med J Aust 2016;204(2):e1-9.

60. Ismail H, Ho KM, Narayan K, Kondalsamy-Chennakesavan S. Effect of neuraxial anaesthesia on tumour progression in cervical cancer patients treated with brachytherapy: A retrospective cohort study. Br J Anaesth 2010;105(2):145-9.

61. Hussain MA, Pati S, Swain S, Prusty M, Kadam S, Nayak S. Pattern and trends of cancer in odisha, India: A retrospective study. Asian Pac J Cancer Prev 2012;13(12):6333-6.

62. Zeng WJ, Hu WQ, Wang LW, Yan SG, Li JD, Zhao HL, et al. Long term follow up and retrospective study on 533 gastric cancer cases. BMC Surg 2014;14(12):29.

63. Ajuzieogu OV, Ezike HA, Amucheazi AO, Enwereji J. A retrospective study of the outcome of cesarean section for women with severe preeclampsia in a third world setting. Saudi J Anaesth 2011;5(1):15-8.

64. Karaman S, Karaman T, Dogru S, Sahin A, Arici S, Tapar H, et al. Retrospective evaluation of Anesthesia approaches for lumbar disc surgery. J Anesth Clin Res 2014;5(4):1-3.

65. Parekh N, Husaini SW, Russell IF. Caesarean section for placenta praevia: A retrospective study of anaesthetic management. Br J Anaesth 2000;84(6):725-30.

66. Weinger MB, Slagle J, Jain S, Ordonez N. Retrospective data collection and analytical techniques for patient safety studies. J Biomed Inform 2003;36(1-2):106-19.

67. Divatia JV, Ambulkar R. Anesthesia and cancer recurrence: What is the evidence? J Anaesthesiol Clin Pharmacol 2014;30(2):147-50.

68. Sokhal N, Rath GP, Chaturvedi A, Dash HH, Bithal PK, Chandra PS. Anaesthesia for awake craniotomy: A retrospective study of 54 cases. Indian J Anaesth 2015;59(5):300-5.

69. Isais-Agdeppa AT, Bravo L. A five-year retrospective study on the common microbial isolates and sensitivity pattern on blood culture of pediatric cancer patients admitted at the Philippine general hospital for febrile neutropenia. PIDSP J 2005;9(2):19-24.

70. Aruna DS, Prasad KV, Shavi GR, Ariga J, Rajesh G, Krishna M. Retrospective study on risk habits among oral cancer patients in Karnataka Cancer Therapy and Research Institute, Hubli, India. Asian Pac J Cancer Prev 2011;12(6):1561-6.

71. Anis R, Gaballah K. Oral cancer in the UAE: A multicenter, retrospective study. Libyan J Med 2013;8:21782

72. Sassi LM, Cervantes O, Schussel JL, Stramandinoli RT, Guebur MI, Ramos GH. Incidence of second primary oral cancer tumors: A retrospective study. Rev Odontol Ciên 2010;25(4):367-70.

73. Pompa G, Saccucci M, Di Carlo G, Brauner E, Valentini V, Di Carlo S, et al. Survival of dental implants in patients with oral cancer treated by surgery and radiotherapy: A retrospective study. BMC Oral Health 2015; $15: 5$.

74. Munde AD, Karle RR, Wankhede PK, Shaikh SS, Kulkurni M. Demographic and clinical profile of oral lichen planus: A retrospective study. Contemp Clin Dent 2013;4(2):181-5.

75. Da Silva AJ, Rocha AC, Vasti AR, Cury R, Cury M, Cury SE. Retrospective study of the frequency of oral squamous cell carcinoma in the population of volta Redonda, Rio de Janeiro, Brazil. WebmedCentral Oncol 2013;4(11):WMC004446.

76. Deen JF, Krieger EV, Slee AE, Arslan A, Arterburn D, Stout KK, et al. Metabolic syndrome in adults with congenital heart disease. J Am Heart Assoc 2016;5(2):e001132.

77. Bhateja S. High prevalence of cardiovascular diseases among other medically compromised conditions in dental patients: A retrospective study. J Cardiovasc Dis Res 2012;3(2):113-6.

78. Cazzola M, Calzetta L, Bettoncelli G, Cricelli C, Romeo F, Matera MG, et al. Cardiovascular disease in asthma and COPD: A population-based retrospective cross-sectional study. Respir Med 2012;106(2):249-56. 
79. Sari I, Altuntas F, Hacioglu S, Kocyigit I, Sevinc A, Sacar S, et al. A multicenter retrospective study defining the clinical and hematological manifestations of brucellosis and pancytopenia in a large series: Hematological malignancies, the unusual cause of pancytopenia in patients with brucellosis. Am J Hematol 2008;83(4):334-9.

80. Girmenia C, Pagano L, Martino B, D’Antonio D, Fanci R, Specchia G, et al. Invasive infections caused by Trichosporon species and Geotrichum capitatum in patients with hematological malignancies: A retrospective multicenter study from Italy and review of the literature. J Clin Microbiol 2005;43(4):1818-28.

81. Desalu OO, Oluwafemi JA, Ojo O. Respiratory diseases morbidity and mortality among adults attending a tertiary hospital in Nigeria. J Bras Pneumol 2009;35(8):745-52.

82. Alamoudi OS. Prevalence of respiratory diseases in hospitalized patients in Saudi Arabia: A 5 years study 1996-2000. Ann Thorac Med 2006;1(2):76-80.

83. Al Balushi KA, Al-Shibli S, Al-Zakwani I. Drug utilization patterns in the emergency department: A retrospective study. J Basic Clin Pharm 2013;5(1):1-6

84. Shawky H, Tawfik H. Primary Gastrointestinal Non-Hodgkin's Lymphoma:ARetrospective Study with Emphasis on Prognostic Factors and Treatment Outcome. J Egypt Natl Canc Inst 2008;20(4):330-41.

85. Arora N, Manipadam MT, Pulimood A, Ramakrishna BS, Chacko A, Kurian SS, et al. Gastrointestinal lymphomas: Pattern of distribution and histological subtypes: 10 years experience in a tertiary centre in South India. Indian J Pathol Microbiol 2011;54(4):712-9.

86. de Silva IL, Mehr SS, Tey D, Tang ML. Paediatric anaphylaxis: A 5 year retrospective review. Allergy 2008;63(8):1071-6.

87. Shah JM, Shah FR, Atit NB, Kakadiya SR. Interpretation of upper gastrointestinal tract endoscopic biopsies - A retrospective study. Inter J Sci Res 2015;4(9):56-8.

88. Padhi S, Paul TR, Challa S, Prayaga AK, Rajappa S, Raghunadharao D, et al. Primary extra nodal non Hodgkin lymphoma: A 5 year retrospective analysis. Asian Pac J Cancer Prev 2012;13(10):4889-95.

89. Abdull Gaffar B. Gastrointestinal stromal tumors and extragastrointestinal tract neoplasms. South Med J 2010;103(10):1004-8.

90. Agerholm-Larsen B, Nordestgaard BG, Steffensen R, Sørensen TI, Jensen G, Tybjaerg-Hansen A. ACE gene polymorphism: Ischemic heart disease and longevity in 10,150 individuals. A case-referent and retrospective cohort study based on the Copenhagen City Heart Study. Circulation 1997;95(10):2358-67.

91. Daikeler T, Labopin M, Ruggeri A, Crotta A, Abinun M, Hussein AA, et al. New autoimmune diseases after cord blood transplantation: A retrospective study of EUROCORD and the Autoimmune Disease Working Party of the European Group for Blood and Marrow Transplantation. Blood 2013;121(6):1059-64.

92. Simon M, Hahn T, Ford LA, Anderson B, Swinnich D, Baer MR, et al. Retrospective multivariate analysis of hepatic veno-occlusive disease after blood or marrow transplantation: Possible beneficial use of low molecular weight heparin. Bone Marrow Transplant 2001;27(6):627-33.

93. Cherif H, Kronvall G, Björkholm M, Kalin M. Bacteraemia in hospitalised patients with malignant blood disorders: A retrospective study of causative agents and their resistance profiles during a 14-year period without antibacterial prophylaxis. Hematol J 2003;4(6):420-6.

94. Shenoi R, Devrukhkar V, Chaudhuri, Sharma BK, Sapre SB, Chikhale A. Demographic and clinical profile of oral squamous cell carcinoma patients: A retrospective study. Indian J Cancer 2012;49(1):21-6.

95. Labib NA, Elraghi HA, Shoman TH, Othman FH. Epidemiology of oral and pharyngeal cancer at the national cancer institute, Cairo. Med J Cairo Univ 2012;80(1):85-91.

96. Krempels K, Somlyai I, Gyongyi Z, Ember I, Balog K, Abonyi O, et al. A retrospective study of survival in breast cancer patients undergoing deuterium depletion in addition to conventional therapies. J Cancer Res Ther 2013;1(8):194-200.

97. Eltawel M, Abdulmoula M. Malignant skin tumours in Misurata Cancer Center during 2011-2014. MMSJ 2015:2(2);123-6.

98. Mohammad EA, Mansour M, Parichehr K, Farideh D, Amirhossein R, Ahmad SA. Assessment of clinical diagnostic accuracy compared with pathological diagnosis of basal cell carcinoma. Indian Dermatol Online J 2015;6(4):258-62.

99. Al-Maghrabi JA, Al-Ghamdi AS, Elhakeem HA. Pattern of skin cancer in Southwestern Saudi Arabia. Saudi Med J 2004;25(6):776-9.

100. Bomm L, Carvalho RV, Lima FF, Oliveira LN, Tolstoy F, Lobão D. Retrospective analysis of melanocytic lesions in children at the National Cancer Institute-RJ. An Bras Dermatol 2014;89(2):369-71.

101. Övermark M, Koskenmies S, Pitkänen S. A retrospective study of treatment of squamous cell carcinoma in situ. Acta Derm Venereol 2016;96(1):64-7.

102. Krishnatreya M, Kataki AC, Sharma JD, Lahkar K. A retrospective analysis of occupational exposure to pesticides as a possible risk factor for non-melanoma skin cancers. South Asian J Cancer 2015;4(1):47-8.

103. Brar BK, Sethi N, Khanna E. An epidemiological review of skin cancers in Malwa belt of Punjab India: A 3- year clinicopathological study. Sch J Appl Med Sci 2015;3(9D):3405-8.

104. Ochicha O, Edino ST, Mohammed AZ, Umar AB. Dermatological malignancies in kano, Northern Nigeria: A histopathological review. Ann Afr Med 2004;3(4):188-91.

105. Lipozenčić J, Jurakić-Tončić R, Radoš J, Celić D. Epidemiology of nonmelanoma and melanoma skin cancer in Zagreb, Croatia. Acta Dermatovenerol Croat 2008;16(4):193-203.

106. Patil R, Makdani M, Gunjalia A, Gandhi K, Pate H. Retrospective study of papulonodular skin lesions and their clinopathological correlation. Int J Med Sci Public Health 2015;4(5):612-6.

107. Chan A, Morey A, Brown B, Hastrich D, Willsher P, Ingram D. A retrospective study investigating the rate of HER2 discordance between primary breast carcinoma and locoregional or metastatic disease. BMC Cancer 2012;12:555.

108. Committee on Publication Ethics (COPE) Guidelines on Good Publication Practice. The COPE Report; 1999.

109. Recommendations for the Conduct, Reporting, Editing, and Publication of Scholarly Work in Medical Journals. Available from: http://www. icjme.org. [Last updated on 2015]. 